\title{
BIBLIOGRAPHY
}

\author{
Primary Sources (1500-1900)
}

Balfour, Edward (ed.), The Cyclopaedia of India and of Eastern and Southern Asia. Commercial, Industrial and Scientific (London: B. Quaritch, 1885), 3 vol.

Barbosa, Duarte, The Book of... An account of the countries bordering on the Indian Ocean and their inhabitants (London: Hakluyt Society, 1918, original 1518), 2 vol.

Baud, Jean C. and Rochussen, Jan J., De semi-officiële en particuliere briefwisseling tussen .., 1845 - 1851. Introduced and edited by Baud, W.A. (Assen: Van Gorkum, 1983), 3 vol.

Baud, Jean C., Proeve van eene geschiedenis van den handel en het verbruik van opium, in: Bijdragen tot het Koloniaal Instituut 1 (1853), p. 79-220 (sometimes indicated as: Tijdschrift voor Indische Taal-, Land- en Volkenkunde).

Bechtinger, Jos, Het eiland in de Chineesche zee (Batavia: Bruining \& Wyt, 1871).

Bernier, François, Travels in the Mogul Empire AD 1656-1668. A revised and improved edition .. by Archibald Constable (Westminster: Archibald Constable \& Co, 1891); on-line edition Columbia University Libraries Digital Collections.

Bluntschli, J. C. and Brater, K. (ed.), Deutsches Staatswörterbuch (Stuttgart- Leipzig: Expedition des Staats-Wörterbuchs, 1857).

Both, Pieter. De Eerste Landvoogd .. 1568-1615. Gouverneur-generaal van Nederlands-Indië (16og-1614) (Zutphen: Walburg Pers, 1987), ed. Rietbergen, P.; 2 vol.

Broecke, Pieter van den .. in Azië, ed. Coolhaas, W. P. (Den Haag: Nijhoff, 1962); Werken Linschoten Vereniging, LXIII; 2 vol.

Broek, J. A. van den, Oud Oost-Indië. De lotgevallen van Nederlandsch Oost-Indië (Haarlem: Bohn, 1893).

Bronnnen tot de Geschiedenis der Oostindische Compagnie in Perzie, ed. Dunlop, H. in: Rijksgeschiedkundige Publicaties, RGP, GS 72 (The Hague: Nijhoff, 1930).

Dam, Pieter van, Beschrijvinge van de Oostindische Compagnie 1639-1701, in: Rijksgeschiedkundige Publicaties, RGP, GS 63, 68, 74, 76, 83, 87, 96 (The Hague: Nijhoff, $1927 \mathrm{ff}$.).

Dutch Factories in India, 1617-1623. A collection of Dutch East India Company documents pertaining to India, ed. Prakash, O. (New Delhi: Manoharlal Publishers, 1984).

Generale Missiven van Gouverneurs-Generaal en Raden aan Heren XVII der Verenigde Oostindische Compagnie, ed. Coolhaas. W.P. et al. in:Rijksgeschiedkundige Publicaties, RGP (The Hague: Nijhoff, $1964 \mathrm{ff}$.), 13 vol. quoted as GM, I etc.

Gouverneur Van Imhoff op dienstreis in 1739 naar Cochin, Travancore en Tuticorin, en terug over Jaffna en Mannar naar Colombo (Zutphen: Walburg Pers, 2007), ed. Anke Galjaard et al.

Groeneveldt, Willem P., (Geheim) Rapport over het opium-monopolie in Fransch Indo-China in verband met de vraag in hoever beheer in régie van dat middel voor Nederlandsch-Indië wenschelijk is; uitgebracht in voldoening aan artikel 1 van het Gouvernements-besluit van 21 Januari 1890 no. 1 (Batavia: Landsdrukkerij, 1890).

Hill, J. Spencer, The Indo-Chinese Opium Trade considered in relation to its History, Morality and Expediency and its influence on Christian Missions (London: Henry Frowde, 1884).

Hobson-Jobson, A glossary of colloquial Anglo-Indian words ... ed. Yule, Henry and Burnell, A.C. (1886); reprint (Sittingbourne, Kent: Linguasia, 1994).

Hogendorp, Gijsbert Karel van, Bijdragen tot de Huishouding van Staat in het Koningrijk der Nederlanden verzameld ten dienste van de Staten-Generaal ('s Gravenhage: Weduwe Johannes Allart, 1818-1825), 10 vol. 
Indonesia. Selected Documents on Colonialism and Nationalism, 1830-1942 (St. Lucia: University of Queensland Press, 1977), ed. and translated by Penders, Chr. L.

Jonge, J. K. de, a.o. (ed.), De Opkomst van het Nederlandsch Gezag in Oost-Indië (The Hague: Nijhoff, 1862-1909), 17 vols.

Kaempfer, Engelbert, The History of Japan; together with a Description of the Kingdom of Siam (London: Routledge, 1995; original edition London, 1727).

Kerala, De Nederlanders in .. 1663-1701. De Memories en Instructies betreffende het Commandement Malabar van de VOC, ed. S'Jacob, H.K. in: Rijksgeschiedkundige Publicaties, RGP, KS 43 (The Hague: Nijhoff, 1976).

Kipling, Rudyard, In an Opium Factory (original, 1888); web edition published byeBooks@ Adelaide, 2009.

Landerer, Xavier, Ueber Opiumbereitung in der Nähe von Magnesia in Kleinasien, in: Archiv der Pharmazie, 113 (1850), p. 293-297.

Lange, G. A. de, Mijnontginning van Staatswege op Billiton ('s Gravenhaghe: Gebr. Belinfante, 1891).

Linschoten, Jan Huyghen van, Voyage to the East Indies (London: Hakluyt Society, 1885; orig. 1595), 2 vol., ed. by Coke Burnell, A. and Tiele, P.

- Itinerario, voyage ofte schipvaert naer Oost ofte Portugaels Indien, 1579-1592 (The Hague: Nijhoff, 1955-57; orig. 1596), 3 vol.; ed. by Kern, H. and Terpstra, H.

Loudon, John F., De Eerste Jaren der Billiton-Onderneming, in: De Indische Gids (Amsterdam: J. de Bussy, 1883), p. 1-115.

Lyall, Alfred, Asiatic Studies. Religious and Social (London: John Murray, 1884).

Manrique, Fray Sebastien, Travels of ... 1629-1643 (Oxford: Hakluyt Society, 1927), 2 Vol.; ed. by Eckford Luard, C. and Hosten, .H.

Marx, Karl, Das Kapital. Kritik der politischen Ökonomie (orig. 1867; Berlin: Dietz, 1971); 3 vol.

Meiss, Johan H., Eenige bijdragen tot de kennis van den Inwendigen Toestand van Nederl.Indië onder het bestuur van Gouv.-Gen. J.J. Rochussen, 1845-1851 (Leiden: Brill, 1883).

Memories van overgave van gouverneurs van Ambon in de zeventiende en achttiende eeuw, ed. Knaap, Gerrit in: Rijksgeschiedkundige Publicaties, RGP, KS, 62 (The Hague: Nijhoff, 1987).

Metzger, Emil, Das Opium in Indonesien, in: Revue Coloniale Internationale, II (1887), p. 175-202.

Midden-Molukken, Bronnen betreffende de ... 1900-1942 (The Hague: Instituut voor Nederlandse Geschiedenis, 1997), ed. Jobse, P.; 4 vol.

Narain, Brij and Sharma, Sri Ram (ed.), A Contemporary Dutch Chronicle of Mughal India (Calcutta: Susis Gupta, 1957).

Newbold, Thomas John, Political and statistical account of the British Settlements in the Straits of Malacca, viz. Pinang, Malacca, and Singapore; with a history of The Malayan States on the Peninsula of Malacca (London:John Murray, 1839), 2 vol. (reprint London: Oxford University Press. 1971).

Ong-Tae-Hae, The Chinaman Abroad; An Account of the Malayan Archipelago particularly ofJava (London: John Snow, 1850); translated by Medhurst, W. H.; the original is from 1791.

Pelsaert, Francisco De Geschriften van .. over Mughal Indië, 1627 , ed. by Kolff, D. and Santen H. van (The Hague: Nijhoff, 1979), Werken Linschoten Vereniging, LXXXI.

Raffles, Thomas Stamford, The History of Java (London: Black, Parbury etc., 1817). Reprint Oxford University Press, 1965; 2 vol.

- Geschiedenis van Java .. wat betreft de onderwerpen, welke voor Nederland en Indië wetenswaardig zijn met aantekeningen to verbetering, beoordeeling en vervolg; vertaald door Sturler, Jacques Eduard de ('s Gravenhaghe-Amsterdam: Van Cleef, 1836). 
Remington, Joseph P., The Practice of Pharmacy. A Treatise ... (Philadelphia: Lippincott, 1886).

Ro, (A) de, Das Opium in Indonesien. Eine Berichtigung, in: Revue Coloniale Internationale, II (1887), p. 553-555.

Rumphius, Georgius E., De Generale Lant-Beschrijvinge van het Ambonse Gouvernement ... ed. by Buijze, W. (The Hague: Houtschild, 2001), original 1678.

Schouten, Wouter, De Oost-Indische Voyagie; reprint by Breet, Michael(Zutphen: Walburg Pers, 2003, original 1676).

Smith, Arthur H., Chinese Characteristics (New York: Revell Company, 1894).

- The Uplift of China (London: British Young People's Missionary Movement, 1907).

Struick, N. J., Opiumpacht of Opiumregie? ('s-Gravenhage: Cremer, 1889).

Swaving, Christiaan, Een woord over een kongsiehuis en de sterfte onder de mijnwerkers op Billiton, in: Tijdschrift Maatschappij ter bevordering der Geneeskunde, no. 5462 (Batavia: 1869), p. 1-16.

Verbeek, Reinier D., Het Billiton-Debat in de Tweede Kamer. Eenige Beschouwingen naar aanleiding daarvan, in: De Indische Gids (Leiden: Brill, 1892), p. 1-64.

Wiselius, Jakob A. B., De Franschen in Indo-China: geografisch, administratief en economisch overzicht van Fransch Cochin China, Annam en Kambodja (Zaltbommel: Noman, 1878).

- De opium in Nederlandsch-en Britsch-Indie: oeconomisch, critisch, historisch (The Hague: Nijhoff, 1886).

Wood, George B. and Bache, Franklin, The Dispensatory of the United States of America (Philadelphia: Lippincott, 1899); 18th edition revised by Wood, H., Remington, J., Sadtler, S. (1st ed. 1833).

Sources 1900-1940

Addens, Tjako J., The distribution of opium cultivation and the trade in opium (Haarlem: Enschede, 1939).

Baasch, Ernst, Holländische Wirtschaftsgeschichte (Jena: Gustav Fischer, 1927).

Bucknill, John, The Coins of the Dutch East Indies. An Introduction to the Study of the Series (London: Spink, 1931).

Burkhardt, V. R., Chinese Creeds \& Customs (Hong Kong: South China Morning Post, 1957; original ca. 1925).

Cheng, Sih-Gung, Modern China. A Political Study (Oxford: Oxford Clarendon, 1919).

Chimin Wong, K. and Lien-Teh, Wu, History of Chinese Medicine. Being a Chronicle of Medical Happenings in China from Ancient Times to the Present Period (Shanghai: National Quarantine Service, 1936).

Commission d'enquête sur le contrôle de l'opium à fumer en Extrême-Orient (Genève: Société des Nations, 1930), 3 vol.

Cressey, George B., China's Geographic Foundations. A Survey of the Land and Its People (New York: McGraw-Hill, 1934).

Encyclopaedie van Nederlandsch-Indië (Ed. by Lith, P. van der and Snelleman, J.) (The Hague: Nijhoff/Brill, s.d..), ca. 1900-1905.

Haan, F. De, Priangan. De Preanger-Regentschappen onder het Nederlandsch Bestuur to 1811 (Batavia: Genootschap van Kunsten en Wetenschappen, 1910-1912), 4 vol.

Helfferich, Emil, Die Niederländsch-Indischen Kulturbanken (Jena: Gustav Fischer, 1914).

Hosie, Alexander, On the Trial of the Opium Poppy. A narrative of travel in the chief opiumproducing provinces of China (London: George Philip \& Son, 1914), 2 vol.

Indië en het Opium. Een verzameling opstellen betreffende het opiumgebruik(Batavia: Kolff, 1931), ed. Nederlandsch-Indische Grootloge van de Internationale Orde van Goede Tempelieren. 
Kemp, Pieter H. van der, Oost-Indië's Geldmiddelen. Japansche en Chineesche Handel van 1817 op 1818: in- en uitvoerrechten, opium, zout, tolpoorten, kleinzegel, boschwezen, Decima, Canton (The Hague: Nijhoff, 1919).

King, Frank H., Farmers of Forty Centuries or Permanent Agriculture in China, Korea and Japan (London: Cape, 1927; 4th impression 1949).

Kol, H. van, Uit Onze Koloniën. Uitvoerig reisverhaal (Leiden: Sijthoff, 1903).

La Motte, Ellen N., The Opium Monopoly (New York: Macmillan, 1920).

Leur, Jacob C. van, Eenige Beschouwingen betreffende den ouden Aziatischen handel (Middelburg: Den Boer, 1934).

Lewin, Ludwig, Phantastica. Die betäubenden und erregenden Genußmittel (Berlin: Georg Stilke, 1927; second printing).

Lossing Buck, John, Land Utilization in China. A study of 16,786 farms in 168 localities ... 19291933 (New York: Paragon Book Reprint, 1964; original Nanking, 1937).

Mansvelt, W. M., Geschiedenis van de Nederlandsche Handel-Maatschappij (Haarlem: NHM, 1924-1926), 2 vol. (at the occasion of the 10o-year celebration of the NHM).

Mollema, Johan C., De Ontwikkeling van het Eiland Billiton en van de Billiton-Maatschappij ('s Gravenhage: Nijhoff, 1922).

Morse, Hosea B., The Trade and Administration of China (London, New York: Longmans, Green \& Co, 1921).

- The Chronicles of the East India Company trading to China, 1635-1834 (Oxford: Clarendon Press, 1926), 4 vol.

Murdoch, James, A History of Japan. From the Origins ... to 1868 (London: Kegan Paul, 19251926); 3 vol.

Opiumfabriek, Verslag over het jaar ... 1913, 1914, 1916, 1918, 1920 (Batavia: Departement van Gouvernementsbedrijven in Nederlandsch-Indie).

Opiumfabriek, Verslag over het jaar .... 1922, 1924, 1926, 1929, 1932, 1935, 1938 (Batavia: Departement van Financiën in Nederlandsch-Indië).

Opiumregie, Verslag betreffende den Dienst der, over het jaar ... 1916, 1918, 1919, 1920, 1923 (Batavia: Drukkerij Ruygrok - Landsdrukkerij).

Opium- en Zoutregie, Wettelijke bepalingen betreffende opium en andere verdoovende middelen (Batavia: Landsdrukkerij, 1938).

Owen, David E., British Opium Policy in China and India (New Haven: Yale University Press, 1934).

Pernitzsch, M., Shanghai, in: Mitteilungen der Ausland-Hochschule an der Universität Berlin, Abteilung I, Ostasiatischen Studien, XL (1937).

Rawlinson, H. G., British Beginnings in Western India, 1579-1657 (Oxford: Clarendon Press, 1920).

Remer, C.F., (ed.), Readings in Economics for China. Selected Readings with explanatory introduction (Shanghai: Commercial Press, 1933; reprint New York: Garland, 1980).

Richter, Julius, (ed.), Das Buch der deutschen Weltmission (Gotha: Klotz Verlag, 1935).

Rosenberg, Alfred, Der Mythus des 20.Jahrhunderts. Eine Wertung der seelisch-geistigen Gestaltenkämpfe unserer Zeit (München: Hoheneichen Verlag, 1937; orig. 1930).

Rowntree, Joshua, The Imperial Drug Trade. A Re-Statement of the Opium Question ... (London: Methuen, 1906).

Schallmayer, Wilhelm, Vererbung und Auslese. Grundriss der Gesellschaftsbiologie und der Lehre vom Rassedienst (Jena: Fischer, 1920; 4th edition).

Scheltema, J. F., The Opium Trade in the Dutch East Indies, in: The American Journal of Sociology, 13 (1907), p. 79-112, 224-251.

Slingenberg, Johan, De Staatsinrichting van Nederl.-Indië (Haarlem: Tjeenk Willink, 1924).

Stapel, F. W., Aanvullende gegevens omtrent de geschiedenis van het eiland Billiton en het voorkomen van tin aldaar ('s Gravenhage: Mijnbouwmaatschappij Billiton, 1938).

Terry, Charles E. and Pellens, Mildred, The Opium Problem (New York: Bureau of Social Hygiene, 1928). 
Terry's Guide to the Japanese Empire including Korea and Formosa with chapters on Manchuria ... (Boston: Houghton Mifflin Co., 1930).

Thibout, Georges, La Question de l'opium à l'époque contemporaine (Paris: Steinheil, 1912).

Tan Tong Joe, Het Internationale Opiumprobleem (The Hague: L. Gerretsen, 1929; dissertation).

Valk, Marinus H. van der, (ed.), Interpretations of the Supreme Court at Peking; years 1915 and 1916 , in: Sinica Indonesiana, 1 (1949), p. 1-383.

Vessem, Cornelis J. Van, Economische Beschouwingen over de Indische Middelen in het bijzonder de Fiscale Monopolies (Wageningen: Veenman, 1932).

Vleming, J. L., Het Chineesche Zakenleven in Nederlandsch-Indië (Batavia: Uitgave Volkslectuur, 1925).

Willoughby, Westel W., Foreign Rights and Interests in China (Baltimore: The Johns Hopkins Press, 1927), 2 vol.

Wolf, Heinrich, Angewandte Rassenkunde. Weltgeschichte auf biologischer Grundlage (Leipzig: Weicher, 1927).

\section{Literature 1940-present}

Adas, Michael, Prophets of Rebellion. Millenarian Protest Movements against the European Colonial Order (Cambridge: Cambridge University Press, 1987).

Alatas, Syed Hussein, Thomas Stamford Raffles, 1781-1826. Schemer or Reformer? (London: Angus-Robertson, 1971).

Alphen, Jan van, and Aris, Anthony (ed.), Oriental Medicine: An Illustrated Guide to the Asian Arts of Healing (London: Serindia Publications, 1995; Dutch translation Rotterdam: Lemniscaat, 1995).

Anderson, Warwick, The Cultivation of Whiteness. Science, Health and Racial Destiny in Australia (New York: Basic Books, 2003).

Andors, Stephen, China's Industrial Revolution. Politics, Planning and Management, 1949 to the present (London: Robertson, 1977).

Anh Tuân, Hoang, The VOC's import of monetary metals into Tonkin and its impact on seventeenth-century Vietnamese society, in: Worden, N. (ed.), p. 149-172.

Arasaratnam, Sinnappah, Maritime India in the Seventeenth Century (New Delhi: Oxford University Press, 2004).

Auerbach, Sascha, Race, Law and "The Chinese Puzzle" in Imperial Britain (New York: Palgrave Macmillan, 2009).

Avery, Martha, The Tea Road. China and Russia meet across the steppe (Beijing: China Intercontinental Press, 2003).

Baader, Gerhard and Keil, Gundolf (ed.), Medizin im mittelalterlichen Abendland (Darmstadt: Wissenschaftliche Buchgesellschaft, 1982).

Baghdiantz, Ina, a.o., (ed.), Diaspora Entrepreneurial Networks. Four Centuries of History (Oxford/New York: Berg, 2005).

Banks, Erik, The Rise and Fall of the Merchant Banks (London: Kogan Page Ltd., 1999).

Barend-Van Haeften, Marijke, Oost-Indië gespiegeld. Nicolaas de Graaff, een schrijvend chirurgijn van de VOC (Zutphen: Walburg Pers, 1992).

Bastin, John, The Native Policies of Sir Stamford Raffles in Java and Sumatra (Oxford: Clarendon Press, 1957).

Baumler, Alan (ed.), Modern China and Opium. A Reader (Ann Arbor: The University of Michigan Press, 2001).

Bayly, Christopher and Harper, Tim, Forgotten Armies. The Fall of British Asia, 1941-1945 (London: Allen Lane, 2004).

Beattie, Alan, False Economy. A Surprising Economic History of the World (New York: Riverhead Books/ Penguin, 2009). 
Beeching, Jack, The Chinese Opium Wars (New York: Harcourt, 1975).

Bernstein, William, A Splendid Exchange. How Trade Shaped the World (London: Atlantic Books, 2009).

Berridge, Virginia and Edwards, Griffith, Opium and the People. Opiate Use in NineteenthCentury England (London: Allen Lane, 1981).

Betta, Chiara, The Trade Diaspora of Baghdadi Jews: From Ottoman Baghdad to China's Treaty Ports, 1843-1931, in: cbetta@ath.forthnet.gr.

Bingling, Yuan, Chinese Democracies. A Study of the Kongsis of West Borneo, 1776-1884 (Leiden: Leiden University, CNWS Publications, 2000).

Bloembergen, Marieke, De Geschiedenis van de Politie in Nederlands-Indie. Uit Zorg en Angst (Leiden: KITLV uitgeverij, 2009).

Blussé,Leonard, An Insane Administration and an Unsanitary Town: the Dutch East India Company and Batavia (1619-1799), in: Ross, R. and Telkamp, G. (ed.), p. 65-87.

- Strange Company. Chinese Settlers, Mestizo Women and the Dutch in VOC Batavia (Leiden: RU Leiden, 1986).

- Tribuut aan China. Vier eeuwen Nederlands-Chinese betrekkingen (Amsterdam: Cramwinckel, 1989).

- Visible Cities. Canton, Nagasaki and Batavia and the coming of the Americans (Cambridge, Mass.: Harvard University Press, 2008).

Boekhout van Solinge, Tim, Dealing with Drugs in Europe. An Investigation of European Drug Control Experiences: France, the Netherlands and Sweden (The Hague: Willem Pompe Institute-BJu Legal Publishers, 2004).

Boomgaard, Peter, Droefenis en duurzaamheid. Beheer en exploitatie van de bossen op Java onder Daendels (1808-1810), in: Jaarboek voor Ecologische Geschiedenis 2009, p. 53-77.

Booth, Anne a.o., (ed.), Indonesian Economic History in the Dutch Colonial Era (New Haven: Yale University, Southeast Asia Studies, 1990).

Bouman, B., Iedervoor zich en de Republiekvoor ons allen. De logistiek achter de Indonesische Revolutie, 1945-1950 (Amsterdam: Boom, 2006).

Bouman, Ferry a.o., Kruidenier aan de Amstel. De Amsterdamse Hortus volgens Johannes Snippendaal, 1646 (Amsterdam: Amsterdam University Press, 2007).

Boussel, Patrice and Bonnemain, Henri, Histoire de la Pharmacie ou 7000 Ans pour Soigner L'Homme (Paris: Editions de la Porte Verte, 1977).

Bovenkerk, Frank and Yeşilgöz, Yücel, De Maffia van Turkije (Amsterdam: MeulenhoffKritak, 1998).

Boxer, C. R., The Dutch Seaborne Empire, 160o-180o (London: Penguin Books, 1965). , Jan Compagnie in Oorlog en vrede. Beknopte geschiedenis van de VOC (Bussum: Unieboek, 1977).

— Portuguese Conquest and Commerce in Southern Asia, 1500-1750 (London:Variorum Reprints, 1985)

Brendon, Piers, The Decline and Fall of the British Empire, 1781-1997 (London:Vintage , 2008).

Brenner, Robert, Merchants and Revolution. Commercial change, political conflict and London's Overseas Traders, 1550-1653 (London: Verso, 2003).

Braudel, Fernand, Civilization and Capitalism, 15th-18th century (London: Collins, 1983).

Brouwer, C., Dutch-Yemeni Encounters. Activities of the United East India Company (VOC) in South Arabaian Waters since 1614 (Amsterdam: D'Fluyte Rarob, 1999).

—, Al-Mukha. The Transoceanic Trade of a Yemeni Staple Town as Mapped by Merchants of the VOC, 1614-1640 (Amsterdam: D'Fluyte Rarob, 2006).

Brown, Ian, The End of the Opium Farm in Siam, 1905-7, in: Butcher, J. and Dick, H. (ed.), p. $233-249$.

Buchanan, Keith, The Transformation of the Chinese Earth. Perspectives of Modern China (London: Bell, 1973). 
Burger, D. H., Sociologisch-economische geschiedenis van Indonesia (The Hague: Nijhoff, 1975), 2 vol.

Butcher, John and Dick, Howard (ed.), The Rise and Fall of Revenue Farming. Business Elites and the Emergence of the Modern State in Southeast Asia (New York: St. Martin's Press, 1993).

Campen, Cretien van, Gedrogeerde deuren van de waarneming, in: Psychologie \& Maatschappij, 20 (1996), p. 374-387.

Carr, Caleb, The Devil Soldier. The Story of Frederic Townsend Ward (New York: Random House, 1992).

Cashmore, Ellis (ed.), Dictionary of Race and Ethnic Relations (London: Routledge, 1994).

Central Intelligence Agency (CIA), An Examination of the Charges of Chinese Communist Involvement in the Illicit Opium Trade (Secret Intelligence Memorandum, CIA/RR IM-438, 9 November, 1956).

Cesarani, David and Romain, Gemma (ed.), Jews and Port Cities, 1590-1990. Commerce, Community and Cosmopolitanism (London: Valentine Mitchell, 2006).

Chaloemtiarana, Thak, Thailand. The Politics of Despotic Paternalism (Suthep, Th.: Silkworm Books-Cornell Southeast Asia Program, 2007).

Chandra, Siddharth, What the Numbers Really tell us about the Decline of the Opiumregie, in: Indonesia, 70 (2000), p. 101-123.

- The Role of Government Policy in Increasing Drug Use: Java, 1875-1914, in: The Journal of Economic History, 62 (2002), p. 1116-1121.

- Economic Histories of the Opium Trade, in: http://eh.net/encyclopedia/article/ chandra/.opium; 02-05-2010.

Chang, Jung and Halliday, Jon, Mao. The Unknown Story (London: Vintage Books, 2007).

Chan, Kwok Bun, Smoke and Fire. The Chinese in Montreal (Hong Kong: Chinese University Press, 1991).

Chapman, Stanley, The Rise of Merchant Banking (Aldershot: Gregg Revivals, 1992).

Chatterjee,Kumkum, Merchants, Politics and Society in Early Modern India. Bihar: 1733-1820 (Leiden: Brill, 1996).

Chaudhuri, K. N., The Trading World of Asia and the English East India Company, 1660-1760 (Cambridge: Cambridge University Press, 1978).

- India's Foreign Trade and the Cessation of the East India Company's Trading Activities, 1828-40, in: Siddiqi, A. (ed.), p. 290-321.

- Asia before Europe. Economy and civilization of the Indian Ocean from the rise of Islam to 1750 (Cambridge: Cambridge University Press, 1990; eighth printing, 2005, under a slightly different title).

Chesneaux, Jean, Secret societies in China in the nineteenth and twentieth centuries (London: Heinemann, 1971).

Chien-Nung, Li The Political History of China, 1840-1928 (Princeton: Van Nostrand, 1956).

Chipman, Leigh, The World of Pharmacy and Pharmacists in Mamlūk Cairo (Leiden: Brill, 2010).

Chouvy, Pierre-Arnaud, Opium. Uncovering the Politics of the Poppy (London: Tauris, 2009).

Chu, Yiu-Kong, International Triad Movements. The Threat of Chinese Organised Crime, in: Conflict Studies, 291 (1996), p. 1-25.

Clarence-Smith, Gervase, The third Portuguese empire, 1825-1975. A study in economic imperialism (Manchester: Manchester University Press, 1985).

Clarke, Robert C., Hashish! (Los Angeles: Red Eye Press, 1998).

Collis, Maurice, Foreign Mud, being an account of the Opium Imbroglio at Canton in the 1830 s and the Anglo-Chinese war that followed (New York: New Directions, 2002; originally 1946).

Courtwright, David T., Dark Paradise. Opiate Addiction in America before 1940 (Cambridge, Mass.: Harvard University Press, 1982). 
Creutzberg, P., Changing Economy in Indonesia: A Selection of Statistical Source Material from the Nineteenth Century up to 1940. Volume 2: Public Finance 1816-1939 (The Hague: Nijhoff, 1976).

Cribb, Robert, Opium and the Industrial Revolution, in: Modern Asian Studies, 22 (1988), p. 701-722.

Cumings, Bruce, Parallax Visions: Making Sense of American-East Asian Relations at the End of the Century (Durham, NC.: Duke University Press, 1999).

Dale, Stephen F., Islamic Society on the South Asian Frontier. The Mappilas of Malabar, 1498-1922 (London: Clarendon Press, 1980).

Dalrymple, William, The Last Mughal. The Fall of a Dynasty, Delhi, 1857 (London: Bloomsbury, 2009).

Das Gupta, Ashin, Malabar in Asian Trade, 1740-1800 (Cambridge: Cambridge University Press, 1967).

Datta, Kalikinkar, The Dutch in Bengal and Bihar, 1740-1825 A.D. (Delhi: Indological Publishers, 1968).

Davids, C. A. a. o. (ed.), Kapitaal, Ondernemerschap en Beleid (Amsterdam: NEHA, 1996).

Davis, Lance E. and Huttenback, Robert, Mammon and the Pursuit of Empire. The Economics of British Imperialism (Cambridge: Cambridge University Press, 1988).

Dear, I. C. and Foot, M.(ed.), The Oxford Companion to World War II (Oxford: Oxford University Press, 2001).

Departement van Koloniën, Het Beheer in Nederland van de Geldmiddelen der Overzeesche Gebiedsdeelen in de Jaren 1940-43 (Zutphen: Thieme \& Cie, 1945).

Derks, Hans, Karl Marx en Lawrence Krader over de "Aziatische Produktiewijze”: van 'externe theorie' tot intern probleem (Amsterdam: University of Amsterdam, 1978-1; Ph.D-thesis).

—, Stad-Land tegenstellingen en de "Aziatische Produktiewijze" (Amsterdam: University of Amsterdam, 1978-2).

- Stad en Land, Markt en Oikos (Amsterdam: University of Amsterdam, 1986; Doctor diss.).

- (ed.), Kroniek van 3 eeuwen revoluties (Groningen: Wolters-Noordhoff, 1989).

, A Note on homogalaktes in Aristotle's Politics, in: Dialogue d'histoire ancienne (CNRS), 21.2 (1995), p. 27-40.

—, Autarkeia in Greek theory and practice, in: The European Legacy, 6 (1996), p. 1915-1933.

- Nomads in Chinese and Central Asian History. The Max Weber Case, in: Oriens Extremus, 41 (1999), p. 7-34.

_, Jew, Nomad or Pariah. Studies on Hannah Arendt's Choice (Amsterdam: Aksant Acad. Publisher, 2004).

_, Religion, capitalism and the rise of double-entry bookkeeping, in: Accounting, Business \& Financial History, 18 (2008), p. 187-213.

Descours-Gatin, Chantal, Quand L'Opium Finançait la Colonisation en Indochine. L'élaboration de la régie générale de l'opium (1860 à 1914) (Paris: l'Harmattan, 1992).

Diehl, F. W., Revenue Farming and Colonial Finances in the Netherlands East Indies, 18161925, in: Butcher, J. and Dick, H.(ed.), p. 196-233.

Dikötter, Frank, Sex, Culture and Modernity in China. Medical Science and the Construction of Sexual Identities in the Early Republican Period (London: Hurst \& Co., 1995)

- Crime, Punishment and the Prison in Modern China (New York: Columbia University Press, 2002).

- and Sautman, Barry (ed.), The Construction of Racial Identities in China and Japan. Historical and Contemporary Perspectives (London: Hurst \& Co., 1997).

- Laamann, Laaman and Xun, Zhou, Narcotic Culture. A Social History of Drug Consumption in China, in: British Journal of Criminology, 42 (2002), p. 317-336. 
Dillo, Ingrid, De nadagen van de Verenigde Oostindische Compagnie, 1783-1795 (Amsterdam: Bataafsche Leeuw, 1992).

Dodge, Ernest, Islands and Empires. Western Impact on the Pacific and East India (Minneapolis: University of Minnesota Press, 1976).

Dormandy, Thomas The Worst of Evils. The Fight against Pain (New Haven: Yale University Press, 2006).

Duco, Don H., Opium \& Opiumschuiven; een bronnenboek (Amsterdam: Stichting Pijpenkabinet, 2006).

Durrenberger, Paul (ed.), State Power and Culture in Thailand (New Haven, Con.: Yale University Press, 1996).

Ebben, Maurits and Wagenaar, Pieter (ed.), De Cirkel doorbroken. Met nieuwe ideeën terug naar de bronnen. Opstellen over de Republiek (Leiden: Instituut voor Geschiedenis, 2006).

Eberhard, Wolfram, A History of China (London: Routledge \& Kegan Paul, 1977).

Eckart, Wolfgang U., Medizin und Kolonialimperialismus Deutschland, 1884-1945 (Paderborn, etc.: Schöningh, 1997).

Eldridge, William B., Narcotics and the Law. A Critique of the American Experiment in Narcotic Drug Control (Chicago: University of Chicago Press, 1967).

Elvin, Mark, The Pattern of the Chinese Past (Stanford, Cal.: Stanford University Press, 1973).

Endacott, G. B., A History of Hong Kong (Hong Kong: Oxford University Press, 1977).

Erfurt, Jürgen, Frankophonie (Tübingen: UTB, 2005).

Evans, Grant, A Short History of Laos. The Land in Between (Crows Nest, Australia: Allen\&Unwin, 2002).

Fairbank, John K. (ed.), The Cambridge History of China (Cambridge: Cambridge University Press, 1983), vol. 12. Republican China 1912-1949.

Feddema, Raymond (ed.), Wat beweegt de Bamboe? Geschiedenissen in Zuidoost Azie (Amsterdam: Spinhuis, 1992).

Fenby, Jonathan, The Penguin History of Modern China. The Fall and Rise of a Great Power, 1850-2009 (London: Penguin Group, 2009).

Ferguson, Niall, Empire. How Britain Made the Modern World (London: Penguin, 2007).

Feuerwerker, Albert, Economic trends in the late Ch'ing empire, 1870-1911, in: Twitchett, D. and Fairbank, J., p. 1-69.

Fischer, Benjamin Louis, "Opium Pushing and Bible Smuggling”: Religion and the Cultural Politics of British Imperialist ambition in China (Notre Dame, Indiana: University of Notre Dame, 2008), dissertation; etd.nd.edu/ETD-db/theses/available/etd...172638/.../ FischerBL042008.pdf

Fischer-Tiné, Harald and Mann, Michael (ed.), Colonialism as civilizing mission. Cultural ideology in British India (London: Anthem Press, 2004).

Foster, Anne L., Prohibition as Superiority: Policing Opium in South-East Asia, 1898-1925, in: The International History Review, 22 (2000), p. 253-273.

- Prohibiting Opium in the Philippines and the United States: The Creation of an Interventionist State, in: McCoy, A. W. and Scarano, F. (ed.), p. 95-106.

Furber, Holden, Rival Empires of Trade in the Orient, 1600-180o (New Delhi: Oxford University Press, 2004).

Furnivall, J. S., Colonial Policy and Practice. A Comparative Study of Burma and Netherlands India (Cambridge: Cambridge University Press, 1948).

Gaastra, Femme S., De geschiedenis van de VOC (Zutphen: Walburg, 1991).

— De VOC als voorloper van de koloniale staat, in: Leidschrift, 15 (2000), p. 7- 21.

, De Amfioen Sociëteit. Een geprivilegieerde handelsmaatschappij onder de vleugels van de VOC, 1745-1794, in: Ebben, M. and Wagenaar, P. (ed.), p. 101-115.

Geddes, William R., Peasant Life in Communist China (Ithaca, NY: Cornell University Press, 1963). 
Geertz, Clifford, Negara. The Theatre State in Nineteenth-Century Bali (Princeton, NJ: Princeton University Press, 1980).

Gelber, Harry G., The Dragon and the Foreign Devils. China and the World, 1100 BC to the present (London: Bloomsbury, 2007).

, China as "Victim"? The Opium War That Wasn't, in: Harvard Center for European Studies, Working Paper Series \#136 (2007).

Gerritsen, W., De Chinese Opium-entrepreneurs in Java.James Robert Rush' histoire integrale .... (Nijmegen: KU Nijmegen, 1982; doctoraal scriptie).

Gerritsen, Jan-Willem, De Politieke Economie van de Roes. De ontwikkeling van reguleringsregimes voor alcohol en opiaten (Amsterdam: Amsterdan University Press, 1993).

Glamann, Kristof, Dutch-Asiatic Trade, 1620-1740 (Copenhagen: Danish Science Press, 1958).

Göckenjan, Gerd, Kurieren und Staat machen. Gesundheit und Medizin in der bürgerlichen Welt (Frankfurt a.M.: Suhrkamp, 1985).

Goh, Daniel P.S., Unofficial contentions: The postcoloniality of Straits Chinese political discourse in the Straits Settlements Legislative Council, in:Journal of Southeast Asian Studies, 41 (2010), p. 483-507.

Goody, Jack, The East in the West (Cambridge: Cambridge University Press, 1998).

Goor, Jan van (ed.), Trading Companies in Asia, 1600-1830 (Utrecht: HES, 1986).

Gootenberg, Paul (ed.), Cocaine. Global Histories (London: Routledge, 1999).

Gossett, Thomas F., Race. The History of an Idea in America (New York: Schocken Books, 1963).

Goto-Shibata, Harumi, The International Opium Conference of 1924-25 and Japan, in: Modern Asian Studies, 36 (2002), 969-991.

Gray, John, Rebellions and Revolutions. China from the 180os to the 1980s. (Oxford: Oxford University Press, 1990).

Greenberg, Michael, British Trade and the Opening of China, 1800-1842 (Cambridge: Cambridge University Press, 1951/1969).

Gruythuysen, M. and Kramer, R., Inventaris van het Direktie-archief van de n.v. BillitonMaatschappij, 1852-1970 (Den Haag: Algemeen Rijksarchief, 1990).

Guha, Amalendu, The Comprador Role of Parsi Seths, 1750-1850, in: Economic and Political Weekly (1972), p. 1933-1936 (www.cscsarchive.org).

Habib, Irfan, Essays in Indian History. Towards a Marxist Perception (New Delhi: Tulika, 1997).

Haccou, J. F., De Indische Exportproducten. Hun beteekenis voor Indië en Nederland (Leiden: Stenfert Kroese, 1947).

Hall, D. G., A History of South-East Asia (London: Macmillan, 1966).

Hall, C. J. van and Koppel, C. van de (ed.), De Landbouw in den Indischen Archipel (The Hague: Van Hoeve, 1946-1950); vol. 1, IIa, IIb, III.

Halperin, Sandra, War and Social Change in Modern Europe. The Great Transformation Revisited (Cambridge: Cambridge University Press, 2004).

Hamilton - Merritt, Jane, Tragic Mountains. The Hmong, the Americans, and the secret wars for Laos, 1942-1992 (Bloomington: Indiana University Press, 1993).

Harrison, Henrietta, Narcotics, Nationalism and Class in China: the transition from opium to morphine and heroin in early twentieth-century Shanxi, in: East Asian History, 32/33 (2007), p. 151-176.

Hayter, Alethea, Opium and the Romantic Imagination (London: Faber and Faber, 1971).

Headrick, Daniel, Power over Peoples. Technology, Environments, and Western Imperialism, 1400 to the present (Princeton: Princeton University Press, 2010).

Hershatter, Gail, The Workers of Tianjin, 1900-1949 (Stanford: Stanford University Press, 1986).

Hillmer, Paul, A People's History of the Hmong (St. Paul, MN.: Minnesota Hist. Soc. Press, 2010). 
Hodder, Rupert, Merchant Princes of the East. Cultural Delusions, Economic Success and the Overseas Chinese in Southeast Asia (Chicester: John Wiley \& Sons, 1996).

Hodgson, Barbara, In the Arms of Morpheus. The Tragic History of Laudanum, Morphine, and Patent Medicines (Buffalo, New York: Firefly Books, 2001).

Hull, Isabel V., Absolute Destruction. Military culture and the Practices of War in Imperial Germany (Ithaca: Cornell University Press, 2005).

Inglis, Brian, The Forbidden Game. A Social History of Drugs (New York: Scribner's Sons, 1975).

Ingold, Tim (ed.), Companion Encyclopedia of Anthropology. Humanity, Culture and Social Life (London: Routledge, 1997).

Isaacs, Harold, New Cycle in Asia. Selected Documents on Major International Developments in the Far East, 1943-1947 (New York: Macmillan, 1947).

Jacobs, Els M., Merchant in Asia. The Trade of the Dutch East India Company during the Eighteenth Century (Leiden: CNWS Publications, 2006).

s'Jacob, Hugo K., Het Hof van Cochin 1670-1710. VOC dienaren als informanten, in: LocherScholten, Elsbeth and Rietbergen, Peter (ed.), p. 201-227.

Jacques, Martin, When China rules the World. The Rise of the Middle Kingdom and the End of the Western World (London: Allen Lane, 2009).

Jelsma, Martin and Kramer,Tom, The Opium Decline: Figures, Facts \& Fiction, in: Drugs $\&$ Conflict $[D \& C]$, August 2008 (Transnational Institute, Amsterdam).

Jennings, John M., The Forgotten Plague: Opium and Narcotics in Korea under Japanese Rule, 1910-1945, in: Modern Asian Studies, 29 (1995), p. 795-815.

- The Opium Empire. Japanese Imperialism and Drug Trafficking in Asia, 1895-1945 (Westport: Praeger, 1997).

Ji, Zhaojin, A History of Modern Shanghai Banking. The Rise and Decline of China's Finance Capitalism (London: Sharpe, 2003).

Jong, Anton W. K. de, Coca, in: Hall, J. van and Koppel, C. van de (ed.), vol. IIa, p. 866-888.

Ka, Chih-ming,Japanese Colonialism in Taiwan. Land Tenure, Development, and Dependency, 1895-1945 (Oxford: Westview Press, 1995).

Kamen, Henry, Empire. How Spain became a World Power, 1492-1763 (New York: HarperCollins, 2003).

Karch, S.B., A Brief History of Cocaine. From Inca Monarchs to Cali Cartels: 500 Years of Cocaine Dealings (Boca Raton, Fl.: Taylor \& Francis, 2006).

Kaufmann, Doris (ed.), Geschichte der Kaiser-Wilhelm-Gesellschaft im Nationalsozialismus. Bestandsaufnahme und Perspektiven der Forschung (Göttingen:Wallstein Verlag, 2001), 2 vol.

Kennedy, John G., The Flower of Paradise. The Institutionalized Use of the Drug Qat in North Yemen (Dordrecht: Reidel, 1987).

Kiernan,Victor, The Lords of Human Kind. European Attitudes to Other Cultures in the Imperial Age (London: Serif, 1995; original 1969).

Kirby, R.J., Urbanisation in China: Town and Country in a developing economy, 1949-200o AD (London: Croom Helm, 1985).

Klein, Axel, Drugs and the World (London: Reaktion Books, 2008).

Klein, Thoralf and Zöllner, Reinhard (ed.), Karl Gützlaff(1803-1851) und das Christentum in Ostasien. Ein Missionar zwischen den Kulturen (Nettetal: Steyler, 2005).

Klimburg, Alexander, Some research notes on Carl A. Trocki's publication Opium, empire and the global political economy, in: Bulletin of the School of Oriental and African Studies, 64 (2001), p. 260-267.

Knaap, Gerrit and Teitler, Ger (ed.), De Verenigde Oost-Indische Compagnie tussen oorlog en diplomatie (Leiden: KITLV Press, 2002).

- and Sutherland, Heather, Monsoon Traders. Ships, skippers and commodities in eighteenth-century Makassar (Leiden: KITLV Press, 2004). 
Kolko,Gabriel, Century of War. Politics, conflicts and society since 1914 (New York: The New Press, 1994).

Korf, Dirk and Riper, Heleen (ed.), Illicit Drug Use in Europe. Proceedings of the 7 th annual conf. on Drug Use and Drug Policy (Amsterdam: SISWO, 1997).

Kort, Marcel de, Tussen patient en delinquent. Geschiedenis van het Nederlandse drugsbeleid (Hilversum: Verloren, 1995).

Kremers, Edward and Urdang, George, History of Pharmacy (Philadelphia: Lippincott, 1963). Revised by Sonnedecker, Glenn.

Kuhn, Philip, Chinese Among Others. Emigration in Modern Times (Lanham, MD: Rowman \& Littlefield, 2008).

Kumar, Dharma and Desai, Meghnad (ed.), The Cambridge Economic History of India (Hyderabad: Orient Longman Limited, 1984), vol. 2. c. 1757-c. 1970.

Kwong, Luke S. K., The Chinese Myth of Universal Kingship and Commissioner Lin Zexu's Anti-Opium Campaign of 1839, in: English Historical Review, cxxiii (2008), p. 1470-1503.

Lamour, Catherine and Lamberti, Michel, The International Connection. Opium from Growers to Pushers (New York: Pantheon Books, 1974).

Lee, Gregory, The British Imperial Addiction: Ideology and Economics and the Chinese Consumption of Opium, in: G. Lee, www.gregorylee.net/ (2010; original French 1998 ?).

Leese, Daniel (ed.), Brill's Encyclopedia of China (Leiden: Brill, 2009).

LeFevour, Edward, Western Enterprise in Late Ch'ing China. A Selective Survey of Jardine, Matheson \& Company's Operations, 1842-1895 (Cambridge, Mass.: Harvard University Press, 1968).

Le Pichon, Alain (ed.), China Trade and Empire.Jardine, Matheson \& Co. and the Origins of British Rule in Hong Kong 1827-1843 (Oxford: Oxford University Press, 2007).

Leuftink, A. E., Harde Leermeesters. Zeelieden en hun dokters in de 18de eeuw (Zutphen: Walburg Pers, 2008).

Leur, Jacob C. van, Indonesian Trade and Society. Essays in Asian Social and Economic History (The Hague: W. van Hoeve , 1955).

Lindemann, Mary, Medicine and Society in Early Modern Europe (Cambridge: Cambridge University Press, 2010).

Lipman, Jonathan N. and Harrell, Stevan (ed.), Violence in China. Essays in Culture and Counterculture (New York: SUNY Press, 1990).

Locher-Scholten, Elsbeth and Rietbergen, Peter (ed.), Hof en Handel. Aziatische vorsten en de VOC, 1620-1720 (Leiden: KITLV Uitgeverij, 2004).

Lodwick, Kathleen L., Crusaders against Opium. Protestant Missionaries in China, 1874-1917 (Lexington: University of Kentucky Press, 1996).

Lossing Buck, John; Dawson, Owen and Wu, Yuan-li, Food and Agriculture in Communist China (New York: Praeger, 1966).

Lovell, Julia, The Opium War. Drugs, Dreams and the Making of China (London: Picador, 2011).

Lubbock, Basil,The Opium Clippers (Glasgow: Brown \& Son, 1953).

Luong, Hy V. (ed.), Postwar Vietnam. Dynamics of a Transforming Society (Singapore: Institute of Southeast Asian Studies, 2003).

Luijk, Eric van and Ours, Jan van, The effect of government policy on drug use: Java, 18751904, in: The Journal of Economic History, 61 (1995), p. 1-17.

Madancy, Joyce A., The Troublesome Legacy of Commissioner Lin. The Opium Trade and Opium Suppression in Fujian Province, 1820 s to 1920 (Cambridge, Mass.: Harvard University Press, 2004).

Madsen, Axel, John Jacob Astor: America's First Multimillionaire (Chicester: John Wiley \& Co, 2001).

Malekandathil, Pius, The Mercantile Networks and the International Trade of Cochin, 1500-1663, in: Veen, E. Van and Blussé, L. (ed.), p. 142-165. 
Manders, Bert, De ontdekking van Tin op het eiland Billiton (Amsterdam: KIT Publishers, 2010).

Manurung, Risma, Amphioen Sociëteit en Amphioen Directie. Inventaris van het archiefvan de Amphioensociëteit en Amphioendirectie te Batavia, 1745-1880 (ANRI: Jakarta, 2007).

Marcus, Abraham, The Middle East on the Eve of Modernity (New York: Columbia University Press, 1989).

Margana, Sri, The formation of a new frontier: the conquest of Java's Oosthoek by the VOC in 1768, in: Worden, N. (ed.), p. 184-207.

, Java's Last Frontier: The Struggle for Hegemony of Blambangan, c. 1763-1814 (Leiden: University Leiden, 2007).

Markovits, Claude, The Political Economy of Opium Smuggling in Early Nineteenth Century India: Leakage or Resistance, in: Modern Asian Studies, 43 (2009), p. 89-111.

Marshall, Jonathan, Opium and the Politics of Gangsterism in Nationalist China, 1927-1945, in: Bulletin of Concerned Asian Scholars, 8 (1976), p. 19-45.

Marshall, Peter J. (ed.), The Oxford History of the British Empire (Oxford: Oxford University Press, 1998), Vol. II, The Eighteenth Century.

Martin, Brian G., The Green Gang and the Guomindang State: Du Yuesheng and the Politics of Shanghai, 1927-37, in:Journal of Asian Studies, 54 (1995), p. 64-91.

- The Shanghai Green Gang. Politics and Organized Crime, 1919-1937 (Berkeley: University of California Press, 1996).

Matheson - Hooker,Virginia, A Short History of Malaysia. Linking East and West (Crows Nest, Australia: Allen\&Unwin, 2003).

Maxwell Hill, Ann, Merchants and Migrants. Ethnicity and Trade among Yunnanese Chinese in Southeast Asia (New Haven, Con.: Yale University Southeast Asia Studies, 1998).

McCoy, Alfred W.; Read, Cathleen B. and Adams, Leonard P., The politics of heroin in Southeast Asia (New York: Harper\&Row, 1972).

McCoy, Alfred W. (ed.), Southeast Asia under Japanese Occupation (New Haven: Yale University Southeast Asia Studies, 1980).

—, and Jesus, C. de (ed.), Philippine Social History: Global Trade and Local Transformations (Quezon City: Metro Manila, 1982).

- , and Block, Alan A. (ed.), War on Drugs. Studies in the Failure of U.S. Narcotics Policy (Boulder-Oxford: Westview Press, 1992).

— and Block, A. (ed.), p. 237- 279.

- and Scarano, Francisco (ed.), The Colonial Crucible. Empire in the Making of the Modern American State (Madison: University of Wisconsin Press, 2009).

McMahon, Keith, The Fall of the God of Money. Opium Smoking in Nineteenth-Century China (Lanham, Maryland: Rowman, 2002).

McPherson, Kenneth, The Indian Ocean. A History of People and the Sea (New Delhi: Oxford University Press, 2004).

Medawar, Charles and Freese, Barbara, Drug Diplomacy. Decoding the conduct of a multinational pharmaceutical company ... (London: Social Audit, 1982).

Mehnert, Ute, Deutschland, Amerika und die "gelbe Gefahr": zur Karriere eines Schlagworts in der grossen Politik, 1905-1917 (Stuttgart: Franz Steiner Verlag, 1995).

Meilink-Roelofsz, M.A., Asian Trade and European Influence in the Indonesian Archipelago between 1500 and about 1630 (Den Haag: Nijhoff, 1962).

—, et al (Ed), The Archives of the Dutch East India Company, 1602-1795 (The Hague: SDU, 1992).

Menghong, Chen, De Chinese gemeenschap van Batavia, 1843-1865. Een onderzoek naar het Kong Koan Archief (Leiden: University of Leiden, 2009; diss.).

Merlin, Mark David, On the Trail of the Ancient Opium Poppy (London: Associated University Press, 1984). 
Meyer, David R., Hong Kong as a Global Metropolis (Cambridge: Cambridge University Press, 2000).

Michael, F. and Chang, Chung-li, The Taiping Rebellion. History and documents (Seattle: University of Washington Press, 1966-1971).

Miskel, James F., British Reaction to the Opium Trade, 1839-186o (Ann Arbor: University Microfilms International, 1979; original 1977).

Mori,Yoshizo, Evolution of Japan opium: empire and its successive invasions to China, Korea and the Southeastern Asias, in: Bulletin of the Yamagata University. Social Science (2005), p. 17-57 (in Japanese).

Moulton, Harold and Marlio, Louis, The Control of Germany and Japan (Washington: The Brookings Institution, 1944).

Mousnier, Roland, Peasant Uprisings in Seventeenth-century France, Russia and China (New York: Harper, 1972).

Munn, Christopher, Anglo-China. Chinese People and British Rule in Hong Kong, 1841-1880 (Richmond: Curzon, 2001).

Murakami, Ei, The Collapse of the Trade Control System of the Qing Government. The opium trade before the Opium War. Workshop on Chinese Economic History (Yokohama National University: May 2009).

Murphy, Rhoads and Stapleton, Kirstin, East Asia. A New History (Boston: Longman, 2010). Musto, David F., The American Disease. Origins of Narcotic Control (New York: Oxford University Press, 1987).

— www.druglibrary.org/schaffer/history/ophs.htm (Jan 2010).

Nadri, Ghulam, The VOC's engagement with piracy in Western India in the 18th century: perceptions and the construction of social identities, in: Worden, N. (ed.), p.172-184.

Nankoe, Hakiem; Gerlus, Jean-Claude and Murray, Martin, The Origins of the Opium Trade and the Opium Regie in Colonial Indochina, in: Butcher, J. and Dick, H. (ed.), p. $182-196$.

Napier, Priscilla, Barbarian Eye. Lord Napier in China, 1834. The prelude to Hong Kong (London: Brassy's, 1995).

Naquin, Susan and Rawski, Evelyn S., Chinese Society in the Eighteenth Century (New Haven: Yale University Press, 1987).

Narain, Brij and Sharma, Sri Ram (ed.), A Contemporary Dutch Chronicle of Mughal India (Calcutta: Susis Gupta, 1957).

Nederveen Pieterse, Jan, Empire and Emancipation. Power and Liberation on a World Scale (London: Pluto Press, 1989).

Newman, R.K., India and the Anglo-Chinese Opium Agreements, 1907-14, in: Modern Asian Studies, 23 (1989), p. 525-560.

- Opium Smoking in Late Imperial China: A Reconsideration, in: Modern Asian Studies, 29 (1995), p. 765-794.

Niane, D. (ed.), General History of Africa. Africa from the twelfth to the sixteenth century (London: Heinemann, 1984), vol. 4.

Ogot, B. (ed.), General History of Africa. Africa from the sixteenth to the eighteenth century (London: Heinemann, 1992), vol. 5 .

Os, Maurits van, Batavia versus Singapore. De handelsrelatie tussen Nederlands-Indie en de Straits Settlements, 1820-1870 (ESG-PhD thesis, University of Amsterdam, 2002).

Ours, Jan van, The price elasticity of hard drugs; the case of opium in the Dutch East Indies (1923-1938), in:Journal of Political Economy, 103 (1995), p. 261-279.

Overy, Richard (ed.), The Times Complete Historical Atlas of the World (London: Times Books, 2007).

Padwa, Howard, National Security and Narcotics Control in France, 1907-1920, in: Proceedings of the Western Society for French History, 33 (2005), p. 340-351. 
Pan, Lynn, Sons of the Yellow Emperor. A history of the Chinese Diaspora (Tokyo: Kodansha, 1994).

Paoli, Letizia; Greenfield, Victoria and Reuter, Peter, The World Heroin Market. Can Supply Be Cut? (Oxford: Oxford University Press, 2009).

Parmentier, Jan (ed.), Noord-Zuid in Oost-Indisch perspectief(Zutphen: Walburg pers, 2005).

Parthesius, Robert, Dutch Ships in Tropical Waters. The Development of the Dutch East India Company (VOC) Shipping Network in Asia, 1595-166o (Amsterdam: Amsterdam University Press, 2010).

Paulès. Xavier, Les fumeurs d'opium à Canton dans les années 1930, in: Études chinoises, xxiii (2004), p. 141- 180.

Paxton, Robert O., Vichy France. Old Guard and the New Order, 1940-1944 (New York: Colombia University Press, 1982).

Peffer, Nathaniel, Far Eastern Problem, in: Encyclopaedia of the Social Sciences (New York: Macmillan, 1949), vol. 6, p. 92-100.

Perkins, Dwight H.; Wang, Yeh-Chien; Wang Hsiao, Kuo-Ying and Su,Yung-Ming, Agricultural Development in China, 1368-1968 (Chicago: Aldine, 1969).

Phongpaichit, Pasuk and Piriyarangsan, Sungsidh, Corruption and Democracy in Thailand (Bangkok: Chulalongkorn University Press, 1994).

Poonen, T.I., A Survey of the Rise of the Dutch Power in Malabar, 1603-1678 (Trichinopoly: Industrial Scholl Press, 1943).

Porter, Andrew (ed.), The Oxford History of the British Empire (Oxford: Oxford University Press, 1999), vol. 3, The Nineteenth Century.

Prakash, Om, The Dutch East India Company and the economy of Bengal, 1630-1720 (Princeton, NJ: Princeton University Press, 1985).

- European trade and the economy of Bengal in the seventeenth and early eighteenth century, in: Goor, J. van (ed.), p. 19-33.

, Opium Monopoly in India and Indonesia in the Eighteenth Century, in: Itinerario, XII (1988), p. 73-9o.

- The Mughal Empire and the Dutch East Indies Company in the seventeenth century, in: Locher-Scholten, Elsbeth and Rietbergen, Peter (ed.), p. 183-201.

_ Alternative Trading Strategies: The Dutch and the English East India Companies in Asia, 160o-165o, in: Parmentier, J. (ed.), p. 167-177.

— Asian Merchants and the Portuguese Trade in Asia, in: Veen, E. van and Blussé, L.(ed.), p. 131-141.

Quincy, Keith, Harvesting Pa Chay's Wheat. The Hmong \& America's Secret War in Laos (Washington: Eastern Washington University Press, 2000).

Randeraad, Nico (ed.), Mediators between State and Society (Hilversum: Verloren, 1998).

Rapin,Ami-Jacques, Notes sur la technique de la fumerie de l'opium, in: www.sinoptic.ch/ ceria/textes/Notes.fumerie_Rapin.pdf.

Rashid, Ahmed, Descent into Chaos. The world's most unstable region and the threat to global security (London: Penguin Books, 2009).

Raychaudhuri, Tapan and Habib, Irfan (ed.), The Cambridge Economic History of India ((Hyderabad: Orient Longman Limited, 1984), vol. 1, c. 1200-c. $175^{\circ}$.

Recio, Gabriela, Drugs and Alcohol: US Prohibition and the Origins of the Drug Trade in Mexico, 1910-1930, in: Journal Latin American Studies, 34 (2002), p. 21-42.

Reid, Anthony, The Origins of Revenue Farming in Southeast Asia, in: Butcher, J. and Dick, H. (ed.), p. 69-8o.

Reid, Daniel P., Chinese Herbal Medicine (Boston: Shambhala [Random House], 1987).

Remer, C.F. (ed.), Readings in Economics for China. Selected Readings with explanatory introduction (Shanghai: Commercial Press, 1933; reprint New York: Garland, 1980).

Remmelink, Willem, Emperor Pakubuwana II, Priyayi \& Company and the Chinese War (Leiden: University of Leiden, 1990; diss.). 
Renard, Ronald D., Kariang. History of Karen-T'ai relations from the beginnings to 1923 (University of Hawaii: Ph.D dissertation, 1979).

- The Burmese Connection. Illegal Drugs \& the Making of the Golden Triangle (Boulder, Col.: Lynne Rienner, 1996).

- Opium Reduction in Thailand, 1970-200o. A thirty-years journey (Bangkok: Silkworm Books, 2001).

Richards, David, Sex, drugs, death and the law: an essay on human rights and over criminalization (Lanham: Rowman \& Littlefield, 1986).

Richards, John F., The Indian Empire and Peasant Production of Opium in the Nineteenth Century, in: Modern Asian Studies, 15 (1981), p. 59-82.

— Changing Land Use in Bihar, Punjab and Haryana, 1850-1970, in: Idem, 19 (1985), p. 699-732.

_ Opium and the British Indian Empire: the Royal Commission of 1895, in: Idem 36 (2002-1), p. 375-420.

, The Opium industry in British India, in: The Indian Economic and Social History Review, 39 (2002-2), p. 149-180.

Ricklefs, M. C., A History of Modern Indonesia c. 1300 to the present (London: Macmillan, 1981).

- War, Culture and Economy in Java, 1677-1726. Asian and European Imperialism in the Early Kartasura Period (Sydney: Allen \& Unwin, 1993).

Risse, Guenter B. (ed.), Modern China and Traditional Chinese Medicine. A Symposium held at the University of Wisconsin (Springfield, Ill.: Thomas, 1973).

Roberts, J.A.G., The Complete History of China (Chalford: Sutton, 2007).

Roelofsz, M. Antoinette, De Vestiging der Nederlanders ter kuste Malabar (Den Haag: Nijhoff, 1943).

Ross, Robert and Telkamp, Gerard (ed.), Colonial Cities (Dordrecht: Nijhoff, 1985).

Rush, James R., Opium to Java. Revenue Farming and Chinese Enterprise in Colonial Indonesia, 1860-1910 (Ithaca: Cornell University Press, 1990).

Rushby, Kevin, Paradise. A History of the Idea that rules the world (London: Robinson, 2007).

Rutten, Alphons, Dutch transatlantic medicine trade in the eighteenth century (Rotterdam: Erasmus Publishing, 2000).

Saich, Tony and Ven, Hans van de (ed.), New Perspectives on the Chinese Communist Revolution (New York: Sharpe-Armonk, 1995).

Sangar, S. P., Intoxicants in Mughal India, in: Indian Journal of History of Science 16 (1981), p. 202-214.

Santen, Hans W. van, De Verenigde Oostindische Compagnie in Gujarat en Hindustan, 16201660 (Meppel: Krips, 1982).

Schipper, Hans, Macht in de Zeventiende Eeuw. Engeland en Nederland kwantitatief vergeleken (Zutphen: Walburg pers, 2001).

Schmidt, Jan, From Anatolia to Indonesia. Opium Trade and the Dutch community of Izmir, 1820-1940 (Istanbul: Ned. Hist.-Archaeol. Institute, 1998).

Schramm, Stuart R. (ed.), Mao's road to power. Revolutionary Writings, 1912-1949 (New York: Sharpe-Armonk, 1992-2005), 7 vol.

Schulte Nordholt, H., The Spell of Power. A History of Balinese Politics, 1650-1940 (Leiden: KITLV Press, 1996).

Schweinitz Jr., Karl de, The Rise and Fall of British India. Imperialism as Inequality (London: Methuen, 1983).

Scott, J. M., The White Poppy. A History of Opium (London: Heinemann, 1969).

Shahnavaz, S., Afyūn, in: Encyclopaedia Iranica www.iranica.com.

Sheridan, James E., Chinese Warlord. The Career of Feng Yü-hsiang (Stanford, Cal.: Stanford University Press, 1966).

Shih,Vincent Y., The Taiping Ideology. Its sources, interpretations and influences (Seattle/ London: University of Washington Press, 1972). 
Shipway, Martin, Decolonization and its Impact. A Comparative Approach to the End of the Colonial Empire (Oxford: Blackwell, 2008).

Shiraishi, Takashi, An Age in Motion. Popular Radicalism in Java, 1912-1926 (Ithaca: Cornell University Press, 1990).

Shuyun, Sun, The Long March (London: Harper Perennial, 2007).

Siddiqi, Asiya (ed.), Trade and Finance in Colonial India, 1750-186o (Delhi: Oxford University Press, 1995).

—, The Business World of Jamsetjee Jejeebhoy, in: Idem (ed.), p. 186-218.

Sinn, Elizabeth, Preparing Opium for America: Hong Kong and Cultural Consumption in the Chinese Diaspora, in: Journal of Chinese Overseas, 1 (2005), p. 16-42.

Siraisi, Nancy G., Medicine and the Italian Universities, 1250-160o (Leiden: Brill, 2001).

Snapper, I., Chinese Lessons to Western Medicine. A Contribution to Geographical Medicine from the Clinics of Peiping Union Medical College (New York: Interscience Publishers, 1941).

Snow, Philip, The Fall of Hong Kong. Britain, China and the Japanese Occupation (New Haven: Yale University Press, 2003).

Somers, Jan A., Nederlandsch-Indië. Staatkundige ontwikkelingen binnen een koloniale relatie (Zutphen: Walburg Pers, 2005).

Souza, George B., The Portuguese Merchant Fleet at Macao in the Seventeenth and Eighteenth Centuries, in: E. van Veen, L. Blussé (ed.), p. 342-369.

$\longrightarrow$, Opium and the Company: Maritime Trade and Imperial Finances on Java, 16841796, in: Modern Asian Studies, 43 (2009-1), p. 113-133.

$\longrightarrow$, An Anatomy of Commerce and Consumption: Opium and Merchants at Batavia over the Long Eighteenth Century, in: Chinese Southern Diaspora Studies, 3 (2009-2), p. $61-87$.

Spence, Jonathan D., The Search for Modern China (New York: Norton, 1990).

-, The Chan's Great Continent. China in Western Minds (London: Allen Lane, 1998). -, Chiang's Monster, in: New York Review of Books, 25-03-2004, p. 29-31.

Starkey, David J. and Hahn-Pedersen, Morten (ed.), Bridging Troubled Waters. Conflict and Co-operation in the North Sea Region since $155^{\circ}$ (Esbjerg: Fiskeri-og Sǿfartsmuseets Forlag, 2005).

Stevens, Harm, Dutch Enterprise and the VOC, $1602-1799$ (Amsterdam: Rijksmuseum, 1998). Stuart-Fox, Martin, Buddhist Kingdom, Marxist State. The Making of Modern Laos (Bangkok: White Lotus Co, 1996).

Subrahmanyam, Sanjay, State Formation and Transformation in Early Modern India and Southeast Asia, in: Itinerario, XII (1988), p. 91-109.

—, The Portuguese Empire in Asia, 1500-1700: A Political and Economic History (London: Longman, 1993).

- Explorations in Connected History. From the Tagus to the Ganges (Oxford: Oxford University Press, 2005).

Talens, Johan, Een feodale samenleving in koloniaal vaarwater. Staatsvorming, koloniale expansie en ecconomische onderontwikkeling in Banten, West-Java 1600-1750 (Hilversum: Verloren, 1999).

Tarling, Nicholas (ed.), The Cambridge History of Southeast Asia (Cambridge: Cambridge University Press, 1999), Vol. 2-1 (1800-1930s), Vol. 2-2 (1940s-present).

Taylor, Jay,The Generalissimo. Chiang Kai-Shek and the Struggle for Modern China (Cambridge, Mass.: Harvard University Press, 2009).

Terpstra, H., De Nederlanders in Voor-Indie (Amsterdam: Van Kampen, 1947).

Topik, Steven; Marichal, Carlos and Frank, Zephyr (ed.), From Silver to Cocaine. Latin American Commodity and the Building of the World Economy, 1500-200o (Durham: Duke University Press, 2006).

Touwen, Jeroen, Extremes in the archipelago. Trade and economic development in the Outer Islands of Indonesia, 1900-1942 (Leiden: University thesis, 1997). 
Tracy, Sarah W. and Acker, Caroline J. (ed.), Altering American Consciousness. The History of Alcohol and Drug Use in the United States, 1800-200o (Amherst/ Boston: University of Massachusetts Press, 2004).

Transnational Institute, Drugs \& Conflict, TNI-Briefing Series (Amsterdam: TNI, 2001-present).

Tripathi, Amales, Indo-British Trade between 1833 and 1847 and the Commercial Crisis of 1847-8, in: Siddiqi, A. (ed.), p. 265-289.

Trocki, Carl A., Opium and Empire. Chinese Society in Colonial Singapore, 1800-1910 (Ithaca: Cornell University Press, 1990).

— The Collapse of Singapore's Great Syndicate, in: Butcher, J. and Dick, H. (ed.), p. 166-182 (1993).

- (ed.), Gangsters, Democracy, and the State in Southeast Asia (Ithaca, New York: Cornell University, SEAP, 1998).

- Opium, Empire and the Global Economy. A Study of the Asian opium trade, 1750-1950 (London: Routledge, 1999a).

- Political Structures in the Nineteenth and Early Twentieth Centuries, in: Tarling, N. (ed.), vol. 2-1, p. 75-127 (1999b).

- Chinese Capitalism and the British Empire. Paper presented to the International Association of Historians of Asia; Taipei, December 2004.

— Chinese Revenue Farms and Borders in Southeast Asia, in: http://eprints.qut.edu. au/10605/ from 2006.

Truong, Buu Lam, Colonialism Experienced. Vietnamese Writings on Colonialism, 1900-1931 (Ann Arbor: The University of Michigan Press, 2000).

Tsiu-Sen, Lin, China und Japan im Spiegel der Geschichte. Eine Betrachtung anhand des Werdeganges Chinas und Japans (Erlenbach-Zürich: Rentsch Verlag, 1944-1946).

Turnbull, C. M., A History of Singapore, 1819-1988 (Singapore: Oxford University Press, 1996). Twitchett, Denis and Fairbank, John (ed.), The Cambridge History of China (Cambridge University Press: Cambridge, 1980), vol. 11.

UNODC (United Nations Office on Drugs and Crime), Opium Poppy Cultivation in SouthEast Asia. Lao PDR, Myanmar (December 2009).

—, Thirty-third Meeting of Heads of National Drug Law Enforcement Agencies, Asia and the Pacific (Denpasar, Indonesia, 6-9 October 2009).

Uragoda,C., History of Opium in Sri Lanka, in: Medical History, 27 (1983), p. 69-76.

Vandenbosch, Amry, The Dutch East Indies. Its Government, Problems and Politics (Berkeley: University of California Press, 1941).

Vandewiele, Lode, Over het Artikel XIV van de "Ordonnantien ende Statuten der Stadt Ghendt ...", in: Bulletin Cercle Benelux d'Histoire de la Pharmacie, no. 3, 1952, p. 11-19.

Vanvugt, Ewald, Wettig Opium. 350 Jaar Nederlandse Opiumhandel in de Indische Archipel (Amsterdam: Onze Tijd, 1985; 1995 second edition without appendices) with a preface by Wim F. Wertheim.

- Het dubbele gezicht van de koloniaal (Haarlem: Knipscheer, 1988).

-, De schatten van Lombok. Honderd jaar Nederlandse oorlogsbuit uit Indonesië (Amsterdam: Mets, 1995-2).

Veen, Ernst van and Blussé, Leonard (ed.), Rivalry and Conflict. European Traders and Asian Trading Networks in the 16th and 17th Centuries (Leiden: CNWS Publications, 2005).

Vickers,Adrian, Bali-a paradise created (Penguin, 1989; Dutch transl. Nieuwegein: Signature, 1997).

Villiers, John, Trade and Society in the Banda Islands in the Sixteenth Century, in:Modern Asian Studies, 15 (1981), p. 723-750.

Völger, Gisela and Welck, Karin von (ed.), Rausch und Realität. Drogen im Kulturvergleich (Reinbek b.H.: Rowohlt, 1982), 3 vol.

Vos, Reinout, Gentle Janus, Merchant Prince. The VOC and the tightrope of diplomacy in the Malay world, 1740-180o (Leiden: KITLV Press, 1993). 
Vries, Jan de and Woude, Ad van der, Nederland 1500-1815. De eerste ronde van moderne economische groei (Amsterdam: Balans, 1995).

Vries, Jan de, The Industrious Revolution. Consumer behavior and the household economy, 1650 to the present (Cambridge: Cambridge University Press, 2008).

Wakabayashi, Bob T., "Imperial Japanese" Drug Trafficking in China: Historiographic Perspectives, in: Sino-Japanese Studies, 13 (2000), p. 3 - 20.

Wakeman Jr., Frederic, Policing Shanghai 1927-1937 (Berkeley: University of California Press, 1995).

Walker, Timothy D., Doctors, Folk Medicine and the Inquisition. The Repression of Magical Healing in Portugal during the Enlightenment (Leiden: Brill, 2005).

Walker III, William O., Opium and Foreign Policy. The Anglo-American Search for Order in Asia, 1912-1954 (Chapel Hill: The University of North Carolina Press, 1991).

Ward, Kerry, Networks of Empire. Forced Migration in the Dutch East India Company (Cambridge: Cambridge University Press, 2009).

Watson - Andaya, Barbara and Andaya, Leonard, A History of Malaysia (London: Macmillan, 1982).

Weber, Max, Gesammelte Aufsätze zur Religionssoziologie (Tübingen: Mohr, 1920), 3 vol.

Wertheim, Wim, Evolutie en Revolutie. De golfslag der emancipatie (Amsterdam: Van Gennep, 1972).

— p. 104-112.

Westermeyer, Joseph, Opium Smoking in Laos: A Survey of 40 Addicts, in: American Journal of Psychiatry, 131 (1974), p. 165-170.

Westwood, J. N., Endurance and Endeavour. Russian History, 1812-1980 (Oxford: Oxford University Press, 1981).

Wickeren, Arnold van, Geschiedenis van Portugal en van de Portugezen overzee, in: www. colonialvoyage. com.

Willmott, Donald E., The Chinese of Semarang: A Changing Minority Community in Indonesia (Ithaca: Cornell University Press, 1960).

Wills, jr., John E., Pepper, Guns and Parleys. The Dutch East India Company and China, 16221681 (Cambridge, Mss.: Harvard University Press, 1974).

Winks, Robin W. and Low, Alaine (ed.), The Oxford History of the British Empire (Oxford: Oxford University Press, 1999), vol. 5. Historiography.

Woodcock, George, The British in the Far East (London: Weidenfeld \& Nicolson, 1969).

Worden, Nigel (ed.), Contingent lives. Social identity and material culture in the VOC world (Cape Town: University of Cape Town, 2007).

Yawnghwe, Chao T., The Shan of Burma. Memoirs of a Shan Exile (Singapore: Institute of Southeast Asian Studies, 1987).

Yoshida, Reiji (1) Japan profited as opium dealer in wartime China; (2) Opium King's ties believed went to the top; (3) Japan followed West by drug-peddling in China; (4) Narcotics trade boosted army scrip, in: The Japan Times, 30 August 2007 (http://search. japantimes.co.).

Yung-Fa, Chen, The Blooming Poppy under the Red Sun: The Yan'an Way and the Opium Trade, in: Saich, T. and Ven, H.van de (ed.), p. 263-299.

Yu-Wen, Jen, A Further Note on Feng Yun-Shan and Gutzlaff, in:Journal of the Royal Asiatic Society Hong Kong Branch, 17 (1977), p. 228-231.

Zanden, Jan L. van, Over de rationaliteit van het ondernemingsgedrag van de VOC: enkele empirische bevindingen, in: Davids, C. A. a.o. (ed.), p. 409-423.

and Riel, Arthur van, Nederland 1780-1914. Staat, instituties en economische ontwikkeling (Amsterdam: Balans, 2000).

Zeldin, Theodore, France 1848-1945 (Oxford: Oxford University Press, 1977), 2 vol. 